\title{
REVIEW
}

Open Access

\section{Subconjunctival injection of mesenchymal stem cells for corneal failure due to limbal stem cell deficiency: state of the art}

Sara Galindo ${ }^{1,2,3+} \mathbb{D}$, Ana de la Mata ${ }^{1,2,3^{*}+}$, Marina López-Paniagua ${ }^{1,2,3}$, Jose M. Herreras ${ }^{1,2,3}$, Inmaculada Pérez ${ }^{1,3}$, Margarita Calonge ${ }^{1,2,3+}$ and Teresa Nieto-Miguel ${ }^{1,2,3^{*}+}$

\begin{abstract}
Mesenchymal stem cells (MSCs) have unique and beneficial properties and are currently used to treat a broad variety of diseases. These properties include the potential for differentiation into other cell types, secretion of different trophic factors that promote a regenerative microenvironment, anti-inflammatory actions, selective migration to damaged tissues, and non-immunogenicity. MSCs are effective for the treatment of ocular surface diseases such as dry eye, corneal burns, and limbal stem cell deficiency (LSCD), both in experimental models and in humans. LSCD is a pathological condition in which damage occurs to the limbal epithelial stem cells, or their niche, that are responsible for the continuous regeneration of the corneal epithelium. If LSCD is extensive and/or severe, it usually causes corneal epithelial defects, ulceration, and conjunctival overgrowth of the cornea. These changes can result in neovascularization and corneal opacity, severe inflammation, pain, and visual loss. The effectiveness of MSCs to reduce corneal opacity, neovascularization, and inflammation has been widely studied in different experimental models of LSCD and in some clinical trials; however, the methodological disparity used in the different studies makes it hard to compare outcomes among them. In this regard, the MSC route of administration used to treat LSCD and other ocular surface diseases is an important factor. It should be efficient, minimally invasive, and safe. So far, intravenous and intraperitoneal injections, topical administration, and MSC transplantation using carrier substrata like amniotic membrane (AM), fibrin, or synthetic biopolymers have been the most commonly used administration routes in experimental models. However, systemic administration carries the risk of potential side effects and transplantation requires surgical procedures that could complicate the process. Alternatively, subconjunctival injection is a minimally invasive and straightforward technique frequently used in ophthalmology. It enables performance of local treatments using high cell doses. In this review, we provide an overview of the current status of MSC administration by subconjunctival injection, analyzing the convenience, safety, and efficacy for treatment of corneal failure due to LSCD in different experimental models. We also provide a summary of the clinical trials that have been completed, are in progress, or being planned.
\end{abstract}

Keywords: Subconjunctival injection, Cornea, Limbus, Regeneration, Mesenchymal stem cells, Limbal stem cell deficiency, Corneal epithelium

\footnotetext{
* Correspondence: adelamatas@ioba.med.uva.es; tnietom@ioba.med.uva.es

†Sara Galindo and Ana de la Mata contributed equally to this work.

${ }^{\dagger}$ Margarita Calonge and Teresa Nieto-Miguel are co-senior authors.

'Instituto de Oftalmobiología Aplicada (IOBA), Universidad de Valladolid,

Edificio IOBA, Campus Miguel Delibes, Paseo de Belén 17, 47011 Valladolid,

Spain

Full list of author information is available at the end of the article
}

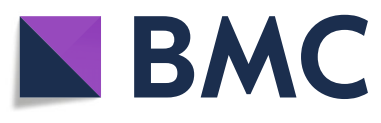

(c) The Author(s). 2021 Open Access This article is licensed under a Creative Commons Attribution 4.0 International License, which permits use, sharing, adaptation, distribution and reproduction in any medium or format, as long as you give appropriate credit to the original author(s) and the source, provide a link to the Creative Commons licence, and indicate if changes were made. The images or other third party material in this article are included in the article's Creative Commons licence, unless indicated otherwise in a credit line to the material. If material is not included in the article's Creative Commons licence and your intended use is not permitted by statutory regulation or exceeds the permitted use, you will need to obtain permission directly from the copyright holder. To view a copy of this licence, visit http://creativecommons.org/licenses/by/4.0/. The Creative Commons Public Domain Dedication waiver (http://creativecommons.org/publicdomain/zero/1.0/) applies to the data made available in this article, unless otherwise stated in a credit line to the data. 


\section{Background}

Corneal damage is one of the main causes of blindness. To safeguard the visual function, it is necessary to preserve corneal transparency, which depends on many factors. One of the critical aspects of corneal transparency is the health of the epithelial barrier, which must be constantly renewed to accomplish its many vital functions. This continuous epithelial turnover is possible because of a population of limbal epithelial stem cells (LESCs) located at the basal layer of the corneoscleral limbal niche [1-4]. Destruction or dysfunction of the LESCs or their niche induces limbal stem cell deficiency (LSCD). LSCD syndrome is characterized by the presence of an unstable epithelium with subsequent ulceration, ingrowth of conjunctival tissue onto the corneal epithelium, neovascularization of the corneal surface, and persistent inflammation and chronic pain, all of which can ultimately cause vision loss due to corneal opacity [5].

Cultivated limbal epithelial transplantation is the current treatment of choice for treating patients suffering from ocular surface failure due to LSCD [6]. Although it represents one of the first and most recognizable successes of regenerative medicine, this treatment is not exempt from limitations, such as the low availability of donors and limited success in the most severe cases [7-10].

Mesenchymal stem cells (MSCs) are considered to be a very attractive candidate for cell-based therapies in several clinical applications. There are already numerous works indicating that the therapeutic effects of MSCs rely not only on their innate differentiation capacity, but also on their immunomodulatory and anti-inflammatory properties to repair damaged tissues [11]. MSCs have been widely studied as a successful therapy to treat ocular surface failure due to LSCD. They facilitate recovery of the corneal epithelium and reduce corneal opacity and inflammation of the ocular surface, not only in experimental models but also in humans [12].

Currently, there is a lack of consensus regarding the best route to administer MSCs to the ocular surface for corneal regeneration. Subconjunctival injection, the focus of the present review, is a straightforward technique that is frequently used in the daily ophthalmologic practice to administer different drugs. This approach employs a simple, safe, and minimally invasive technique to deliver locally high cell doses in a low volume [13].

Besides, there are different techniques that have been commonly used so far. In some preclinical studies, MSCs were administered topically [14-16], using natural or synthetic substrata such as amniotic membrane (AM) [17-21], fibrin [22], or films made of poly-L-lactic acid [14, 23, 24] or polyamide [25]. In other studies, the cells were injected intravenously [26-28], intraperitoneally [29, 30], intracorneostromally [31, 32], or subconjunctivally [33-39]. There are also human clinical studies in which AM [12], sub-tenon injections (clinicaltrials.gov_NCT04224207, NCT02144103, and NCT03011541), or subconjunctival injections are used to administer the MSCs (clinicaltrials.gov_NCT02325843, NCT01808378, NCT04484402, NCT03967275, and NCT03237442). The first clinical trial performed and published using bone marrow (BM)-MSCs on AMs (clinicaltrials.gov_NCT01562002) was demonstrated to be both safe and effective in the restoration of the corneal epithelial phenotype for the treatment and improvement of patients suffering from LSCD [12]. Additionally, sub-tenon injection is also a suitable ocular route of drug administration that involves the delivery of medication or cells through the area between the sclera and the Tenon capsule. For instance, injection of umbilical cord Wharton's jelly-derived MSCs into the sub-tenon space had beneficial effects on visual functions in retinitis pigmentosa patients by reactivating the degenerated photoreceptors (clinicaltrials.gov_NCT04224207) [40]. In addition, two more clinical trials using subtenon injection to transplant adipose tisue (AT)-MSCs (clinicaltrials.gov_NCT02144103) and BM-MSCs (clinicaltrials.gov_NCT03011541) are in progress for the treatment of glaucomatous neurodegeneration and retinal and optic nerve damage, respectively.

However, there are some drawbacks to these administration routes that are not present with subconjunctival injection: (1) systemic administration presents a high risk of side effects, and the number of cells that reach the target tissue is low; (2) topical administration involves loss of cells, as they are not retained on the ocular surface for a long time; and (3) the use of carrier substrata requires a surgical procedure, increasing the cost, while limiting the number of cells that can be transplanted.

In this review, we provide an overview of the current status of MSC administration by subconjunctival injection, analyzing its convenience, safety, and efficacy for the treatment of corneal failure due to LSCD. We also identify clinical trials that are completed, in progress, or that are planned.

\section{Main text}

\section{Use of MSCs for treating corneal epithelial damage}

MSCs constitute an adult stromal stem cell population that originates from the mesoderm. Although BM and $\mathrm{AT}$ are the most utilized sources, MSCs are also present in muscle, cartilage, dental pulp, umbilical cord, placenta, and in the limbal stroma of mammalian eyes, including humans $[11,41]$. To standardize the characterization of these cells, the International Society for Cellular Therapy established three minimal criteria [42]: (1) adherence to plastic surfaces in standard culture conditions; (2) multipotent differentiation potential to form bone, cartilage, and adipose cells in vitro; and (3) 
presentation of a specific surface-antigen expression pattern, including CD90, CD105, and CD73, but without CD34, CD45, CD11b or CD14, CD19 or CD79 $\alpha$, and HLA-DR [42].

Several in vitro and in vivo studies using MSCs for corneal epithelium regeneration have been published recently. All of these works, performed in different animal models, present encouraging results regarding safety, corneal epithelium regeneration, transparency recovery, healing process, and ultimately vision restoration $[17,23$, $26,43]$. These results could be due either to the transdifferentiation of the transplanted MSCs into corneal epithelial cells or to other well-known features of MSCs, such as migration towards the injured areas, secretion of trophic and growth factors capable of stimulating resident stem cells, and reducing tissue injury and inflammation $[23,26,44,45]$.

MSC-secreted growth factors are considered essential for the proliferation and migration of corneal epithelial cells, and they contribute to the corneal epithelium regenerative process [46-49]. The anti-inflammatory action of MSCs is associated with secreted soluble factors $[29,35]$ that suppress the infiltration of inflammatory cells and CD68+ macrophages in the damaged tissue, inhibiting the expression of inflammatory proteins $[16$, 33, 35].

MSCs have reduced expression of major histocompatibility complex (MHC) class I antigens, and they do not express MHC II or co-stimulatory molecules like CD80, CD86, and CD40 [50, 51]. Thus, the MSCs have a nonimmunogenic phenotype, making it possible to use them allogeneically in cornea regeneration and avoiding the need of immunosuppression after transplantation.

\section{MSC administration routes for treating corneal epithelial damage}

The route of MSC delivery is one of the main problems to overcome in achieving optimal benefits from stem cell therapy. While some authors, using either intravenous or intraperitoneal systemic administration of MSCs, reported the migration of stem cells to the injured cornea $[26,28,52]$, others did not [29], suggesting instead that the therapeutic effect was due to the trophic factors secreted by MSCs. Some studies indicate that intravenous administration during the acute phase of corneal epithelial damage can improve clinical signs such as epithelial defects, neovascularization, and corneal opacity, in both mice $[26,28]$ and rabbits [27].

The use of cell carriers for MSC transplantation is one of the most frequently applied techniques. Clinical signs are reduced when MSCs are transplanted to the ocular surface using AM as carrier both in experimental models [17-21] and in humans [12]. However, the cell dose that can be delivered is normally lower than by using other routes. In addition, as a human product, AM has limited availability, risk of disease transmission, and a high economic cost [53]. Another natural carrier is fibrin gel, capable of helping repair the ocular surface when transplanted with or without MSCs [22]. Moreover, synthetic cell carriers such as contact lenses [54], poly-L-lactic acid [14, 23], and polyamide [25] have been studied to find reproducible substrata that allow cell adhesion, viability, proliferation, and regeneration of the ocular surface when they are transplanted with MSCs. However, the number of stem cells delivered by these carriers is limited compared to the cell dose that can be administered by injections. Additionally, most of the substrata require suturing to the ocular surface. This extra step in the surgical intervention and the follow-up surgery to remove the stitches make the whole process more tedious, risky, and expensive.

In contrast to the other delivery protocols, topical administration of MSCs has been used in LSCD experimental models $[14,15]$. While clearly simpler than the delivery methods described above, it has some drawbacks such as low retention time on the ocular surface, high washing rate, and low permeability of the corneal epithelium.

Considering all of the limitations associated with the classic cell transplantation routes, subconjunctival injection has clear advantages and has emerged as a viable alternative route for administering MSCs to the ocular surface. It is minimally invasive and easily achieved in routine clinical care for different treatments. It is normally indicated for the treatment of injuries in the cornea, sclera, anterior uvea, and vitreous. Clinicians regularly use subconjunctival injections of triamcinolone for macular edema [55], anti-microbial drugs for the treatment of infectious keratitis [56], mitomycin $C$ in pterygium surgeries $[57,58]$, and bevacizumad for corneal neovascularization [59, 60] (Fig. 1). Moreover, this technique is described in several preclinical studies to treat different diseases such as uveitis, glaucoma, herpesvirus, inflammation, vascular hyperpermeability, edema, angiogenesis, retinoblastoma, choroidal neovascularization, and corneal grafts [13]. Moreover, it can be used in severe cases of LSCD, allows administration of high cell doses in a small volume, and does not need any extensive additional cell culture steps. Subconjunctival injections do not require the use of a surgical facility, and no additional post-injection interventions are required, resulting in a reduction of time and cost (Fig. 2).

\section{Subconjunctival MSC injection for treating corneal epithelial damage}

In ophthalmology, subconjunctival injection is used to deliver drugs when the topical route is judged insufficient. This approach bypasses the epithelial cell barrier, 


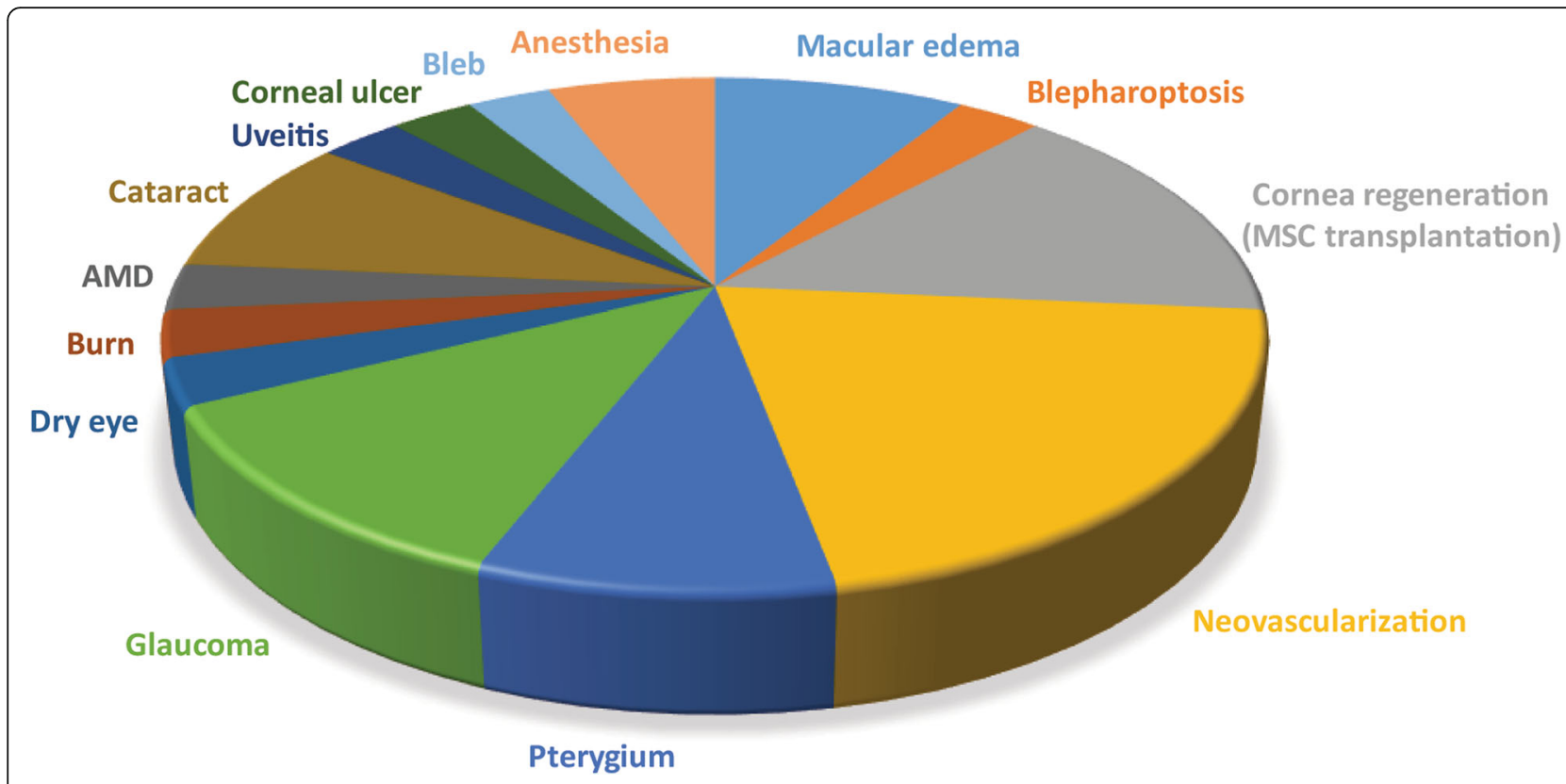

Fig. 1 Pie chart depicting the current application of subconjunctival injections in clinical trials (clinicaltrials.gov). Macular edema (9\%), blepharoptosis (3\%), cornea regeneration (MSC transplantation) (14\%), neovascularization (20\%), pterygium (9\%), glaucoma (12\%), dry eye (3\%), burn (use of vitamin C) (3\%), age-related macular degeneration (AMD) (3\%), cataract (9\%), uveitis (3\%), keratitis (3\%), bleb (3\%), and anesthesia (6\%)

ensuring rapid absorption. It can be used in severe conditions in which a high concentration of drug is needed [61]. Recently, subconjunctival injection has been used to administer MSCs in ocular surface therapy. Although multiple benefits have become evident, it is not easy to compare the published studies, as different animal models, methods, and cell doses and sources have been applied (Table 1).

Animal models of corneal epithelial damage in mice [33, 62], rats [34-36, 38, 63, 64], and rabbits [37, 65, 39] can be classified into two main groups. In one group, damage is restricted to the cornea [34-37, 62-64], whereas in the other group, both the cornea and the limbus are affected [33, 38, 39, 65].

The source of MSCs to be transplanted either allogeneically or xenogeneically is another variable, and BM, AT, and limbal MSCs are the most commonly used [33$39,63]$. For both allogeneic and xenogeneic transplantation, no immunosuppression was performed and no toxic or cell rejection reactions were reported. Therefore, subconjunctivally injected MSCs can be considered as a safe treatment in the different animal models so far reported and are currently being tested in a few clinical trials (see below).

Despite the advantages described above, subconjunctival injections also have five possible limitations, although some could be resolved with new studies. The first limitation is that there is still no consensus regarding the best cell vehicle solution. Second, it is necessary to establish a cell concentration in which the cells do not form clusters and consequently block the syringe during the injection. Third, it is not possible to inject a high volume of solution because it must be retained in and adsorbed by the conjunctiva. Fourth, there is yet no consensus regarding the number and location of the injections. The fifth limitation is that even though the technique is considered to be minimally invasive, it causes some pain in humans, and it could potentially allow an infection to occur.

To organize the information in the present review, we describe the main results regarding the therapeutic reduction of clinical signs such as corneal opacity and vascularization, as well as the anti-inflammatory and immunomodulatory effects. We also present results regarding cell migration and the corneal epithelial regeneration capacity after the subconjunctival MSC injection in experimental models of LSCD and/or corneal epithelial damage. Finally, we present a section that summarizes the clinical trials that are completed, have been planned, or are currently being performed using subconjunctival injections of MSCs for treating corneal epithelial damage in humans.

\section{Therapeutic effects of subconjunctival MSC injection following corneal epithelial damage}

Several studies of corneal regeneration have reported the beneficial therapeutic effects of subconjunctival MSC injection. All the cited studies below used allogeneic cells 


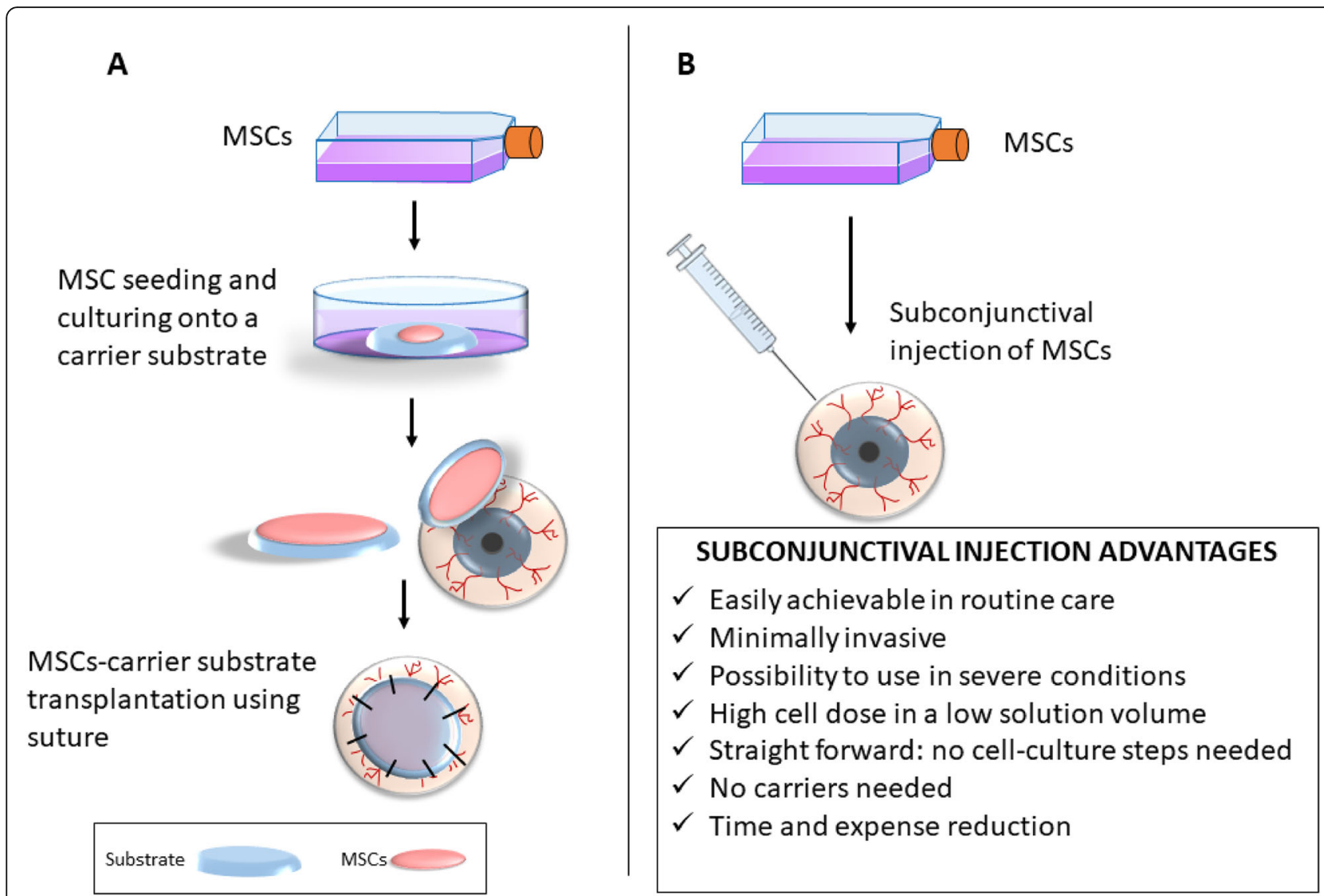

Fig. 2 Comparison of MSC transplantation onto the ocular surface using a carrier substratum (a) versus subconjunctival injection (b). MSCs, mesenchymal stem cells

unless specifically state otherwise. In diabetic mice, after mechanical removal of the corneal and limbal epithelium, subconjunctivally injected BM-MSCs decreased the epithelial defects and improved corneal reepithelization as confirmed by expression of Ki67 in the wound areas [33]. In another study, subconjunctival injection of BM-MSCs in mechanically damaged mice corneas reduced corneal opacity and epithelial defects [62]. Martinez-Carrasco et al., while not specifically studying a model of damage cornea, recently confirmed that the subconjunctival injection of human BM-MSCs in a mouse model of GVHD reduced the keratinization of the corneal epithelium mediated by PAX6 [66].

In addition, Yao et al. studied the effect of BM-MSC administration in a chemical burn model of rat corneas [35]. They applied two subconjunctival injections, immediately after the injury and again 3 days later. After 7 days, neovascularization was decreased as confirmed by the reduction of vascular endothelial growth factor (VEGF) expression, and the fast corneal epithelium recovery. Another study using a rat cornea burn model demonstrated that the use of a single subconjunctival injection of BM-MSCs was more efficient than AM BM-
MSC transplantation [34]; however, the results were not strictly comparable because the number of cells transplanted by the AM was much lower. Nevertheless, the corneas getting subconjunctival BM-MSCs had greater decreases in epithelial defects, corneal opacity, and neovascularization associated with reduced vessel length and VEGF expression. Thus, the subconjunctival injection of BM-MSCs improved corneal wound healing during the 4-week follow-up more efficiently than the AMtransplanted BM-MSCs [34]. In a rat model of corneal alkali burn, the efficacy of subconjunctival BM-MSC injections combined with polysaccharide hydrogel treatment was investigated [36]. The reduction of epithelial defects, neovascularization, and corneal opacity were significantly enhanced by the combined treatment. Zhang et al. compared the subconjunctival injection of TNF- $\alpha-$ pre-stimulated BM-MSCs and non-stimulated BMMSCs in a rat corneal burn model. In both cases, the epithelial defects were reduced. However, the corneal opacity decreased significantly only when TNF- $\alpha$-prestimulated BM-MSCs were administered [64]. Interestingly, some researchers have also demonstrated that rat subconjunctival BM-MSC injections are effective in 
Table 1 Subconjunctival injection of MSCs in experimental models of corneal epithelial damage

\begin{tabular}{|c|c|c|c|c|c|c|c|c|}
\hline Species & $\begin{array}{l}\text { Experimental } \\
\text { model }\end{array}$ & Cell administration route & $\begin{array}{l}\text { Follow- } \\
\text { up } \\
\text { time }\end{array}$ & Clinical signs & $\begin{array}{l}\text { Cell } \\
\text { migration }\end{array}$ & $\begin{array}{l}\text { Anti-inflammatory/ } \\
\text { immunomodulatory } \\
\text { effects }\end{array}$ & $\begin{array}{l}\text { Corneal/ } \\
\text { limbal } \\
\text { markers }\end{array}$ & Reference \\
\hline \multirow[t]{2}{*}{ Mouse } & $\begin{array}{l}\text { Corneal and } \\
\text { limbal } \\
\text { mechanical } \\
\text { removal in } \\
\text { diabetic mice }\end{array}$ & $\begin{array}{l}\text { Mouse BM-MSCs: one injec- } \\
\text { tion }\left(5 \times 10^{4} / 5 \mu \mathrm{l} \text { PBS) im- }\right. \\
\text { mediately after damage }\end{array}$ & $\begin{array}{l}24,48 \\
\text { and } 72 \\
\mathrm{~h}\end{array}$ & $\begin{array}{l}\downarrow \text { Epithelial defect } \\
\uparrow \text { Corneal epithelium } \\
\text { proliferation }\end{array}$ & $\begin{array}{l}\text { Migration } \\
\text { to the } \\
\text { limbal } \\
\text { stroma and } \\
\text { wound } \\
\text { healing } \\
\text { edge }\end{array}$ & $\begin{array}{l}\downarrow \text { Inflammatory } \\
\text { infiltrates } \\
\downarrow \text { CD45, CD86 } \\
\downarrow \mathrm{M} 1 \text { : TNFa, MCP-1 } \\
\uparrow \mathrm{M} 2: \text { CD206, IL-10, } \\
\text { Arg-1 }\end{array}$ & $\begin{array}{l}\uparrow P 63 \\
\downarrow K 12\end{array}$ & $\begin{array}{l}\text { Di et al. } \\
\text { [33] }\end{array}$ \\
\hline & $\begin{array}{l}\text { Corneal } \\
\text { mechanical } \\
\text { removal (2 } \\
\text { mm trephine) }\end{array}$ & $\begin{array}{l}\text { Mouse BM-MSCs: one injec- } \\
\text { tion }\left(5 \times 10^{5} / 10 \mu \mathrm{PBS}\right) 1 \mathrm{~h} \\
\text { after damage }\end{array}$ & $\begin{array}{l}2 \text { and } \\
4 \text { days }\end{array}$ & $\begin{array}{l}\downarrow \text { Epithelial defect } \\
\downarrow \text { Corneal opacity }\end{array}$ & $\begin{array}{l}\text { Migration } \\
\text { to the } \\
\text { cornea and } \\
\text { conjunctiva }\end{array}$ & $\begin{array}{l}\downarrow C D 45 \\
\downarrow \| L-1 \beta, T N F a\end{array}$ & - & $\begin{array}{l}\text { Shukla } \\
\text { et al. [62] }\end{array}$ \\
\hline \multirow[t]{6}{*}{ Rat } & $\begin{array}{l}\text { Corneal } \\
\text { chemical burn } \\
\text { ( } 3 \mathrm{~mm} \varnothing \text { disc/ } \\
1 \mathrm{M} \mathrm{NaOH} 40 \mathrm{~s})\end{array}$ & $\begin{array}{l}\text { Rat BM-MSCs ( } 2 \text { injections } \\
2 \times 10^{6} / 100 \mu \mathrm{l} \text { PBS): one im- } \\
\text { mediately, and one } 3 \text { days } \\
\text { after damage }\end{array}$ & $\begin{array}{l}3-7 \\
\text { days }\end{array}$ & $\begin{array}{l}\downarrow \text { Neovascularization } \\
\downarrow \text { Epithelial defect } \\
\uparrow \text { Corneal epithelium } \\
\text { regeneration }\end{array}$ & $\begin{array}{l}\text { No } \\
\text { migration. } \\
\text { Cells } \\
\text { located in } \\
\text { the } \\
\text { injection } \\
\text { site }\end{array}$ & $\begin{array}{l}\downarrow C D 68 \\
\downarrow M I P-1 a, \text { TNFa }\end{array}$ & - & $\begin{array}{l}\text { Yao et al. } \\
\text { [35] }\end{array}$ \\
\hline & $\begin{array}{l}\text { Corneal } \\
\text { chemical burn } \\
(6 \mathrm{~mm} \varnothing \text { disc/ } \\
1 \mathrm{M} \mathrm{NaOH} 30 \mathrm{~s})\end{array}$ & $\begin{array}{l}\text { Rat BM-MSCs ( } 2 \text { injections } \\
2 \times 10^{6} / 100 \mu \mu \text { PBS + poly- } \\
\text { saccharide hydrogel): one } \\
\text { immediately and one } 2 \\
\text { days after damage }\end{array}$ & $\begin{array}{l}3,7,14 \\
\text { and } 28 \\
\text { days }\end{array}$ & $\begin{array}{l}\downarrow \text { Neovascularization } \\
(\downarrow \text { VEGF and } \uparrow T S P-1) \\
\uparrow \text { Corneal epithelium } \\
\text { regeneration } \\
\downarrow \text { Corneal opacity }\end{array}$ & - & $\begin{array}{l}\downarrow \text { Inflammatory } \\
\text { infiltrate } \\
\uparrow \text { TGF } \beta \\
\downarrow \text { MIP-1a, TNFa }\end{array}$ & - & $\begin{array}{l}\text { Ke et al. } \\
{[36]}\end{array}$ \\
\hline & 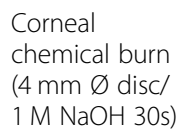 & $\begin{array}{l}\text { Human limbal MSCs: one } \\
\text { injection }\left(2.4 \times 10^{6} / 500 \mu l\right) \\
2 \text { days after damage }\end{array}$ & $\begin{array}{l}1,2,3 \\
\text { and } 4 \\
\text { weeks }\end{array}$ & $\begin{array}{l}\downarrow \text { Corneal opacity } \\
\downarrow \text { Neovascularization } \\
\downarrow \text { Epithelial defect }\end{array}$ & $\begin{array}{l}\text { Migration } \\
\text { to the } \\
\text { corneal } \\
\text { epithelium }\end{array}$ & $\begin{array}{l}\downarrow \text { Inflammatory } \\
\text { infiltrate }\end{array}$ & - & $\begin{array}{l}\text { Acar et al. } \\
\text { [63] }\end{array}$ \\
\hline & $\begin{array}{l}\text { Corneal } \\
\text { chemical burn } \\
\text { ( } 3 \mathrm{~mm} \varnothing \text { disc/ } \\
1 \mathrm{~N} \mathrm{NaOH} \mathrm{30s)}\end{array}$ & $\begin{array}{l}\text { Rat BM-MSCs }\left(1 \times 10^{6} /\right. \\
100 \mu \text { PBS): one injection } 7 \\
\text { days after damage }\end{array}$ & $\begin{array}{l}7,14 \\
21, \text { and } \\
28 \text { days }\end{array}$ & $\begin{array}{l}\uparrow \text { Corneal wound } \\
\text { healing } \\
\downarrow \text { Neovascularization } \\
\text { (\VEGF and MMP-9) } \\
\downarrow \text { Epithelial defect } \\
\downarrow \text { Corneal opacity }\end{array}$ & $\begin{array}{l}\text { No } \\
\text { migration. } \\
\text { Cells } \\
\text { located in } \\
\text { the } \\
\text { injection } \\
\text { site }\end{array}$ & $\begin{array}{l}\downarrow \text { Inflammatory } \\
\text { infiltrate }\end{array}$ & - & $\begin{array}{l}\text { Ghazaryan } \\
\text { et al. [34] }\end{array}$ \\
\hline & 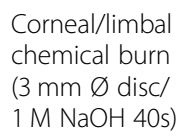 & $\begin{array}{l}\text { Rat BM-MSCs: one injection } \\
\left(2 \times 10^{6} / 100 \mu \mathrm{l} \text { PBS }\right) 3 \text { days } \\
\text { after damage }\end{array}$ & $\begin{array}{l}3,6,9 \\
\text { and } 12 \\
\text { days }\end{array}$ & $\begin{array}{l}\downarrow \text { Corneal opacity } \\
\downarrow \text { Neovascularization }\end{array}$ & - & - & - & $\begin{array}{l}\text { Pan et al. } \\
\text { [38] }\end{array}$ \\
\hline & $\begin{array}{l}\text { Corneal } \\
\text { chemical burn } \\
(6 \mathrm{~mm} \varnothing \text { disc } \\
1 \mathrm{~N} \mathrm{NaOH} 20 \mathrm{~s})\end{array}$ & $\begin{array}{l}\text { Rat BM-MSCs (pre-stimu- } \\
\text { lated with TNF-a and non- } \\
\text { stimulated): one injection } \\
\left(2 \times 10^{6} / 100 \mu \mathrm{ll} \text { PBS) imme- }\right. \\
\text { diately after damage }\end{array}$ & $\begin{array}{l}3,7 \\
\text { and } 14 \\
\text { days }\end{array}$ & $\begin{array}{l}\downarrow \text { Corneal opacity } \\
\downarrow \text { Epithelial defect }\end{array}$ & $\begin{array}{l}\text { No } \\
\text { migration. } \\
\text { Cells } \\
\text { located in } \\
\text { the } \\
\text { injection } \\
\text { site }\end{array}$ & $\begin{array}{l}\downarrow \text { Inflammatory } \\
\text { infiltrates } \\
\downarrow C D 68 \\
\downarrow \text { iNOS, TNFa, IL-1, IL-6, } \\
\text { MCP-1, MIP-1a } \\
\uparrow P T G S 2, \text { TSG-6 }\end{array}$ & - & $\begin{array}{l}\text { Zhang } \\
\text { et al. [64] }\end{array}$ \\
\hline \multirow[t]{3}{*}{ Rabbit } & $\begin{array}{l}\text { Corneal } \\
\text { chemical burn } \\
(7 \mathrm{~mm} \varnothing \text { disc/ } \\
10 \% \mathrm{NaOH} \\
40 \mathrm{~s})\end{array}$ & $\begin{array}{l}\text { Human AT-MSCs }\left(1.3 \times 10^{5} /\right. \\
200 \mu \text { l saline solution): one } \\
\text { injection immediately after } \\
\text { damage }\end{array}$ & 30 days & $\begin{array}{l}\downarrow \text { Epithelial defect } \\
\downarrow \text { Corneal opacity }\end{array}$ & - & - & $\begin{array}{l}\uparrow \text { Connexin- } \\
43 \\
\uparrow \beta \text {-catenin } \\
\text { No } \\
\text { changes in } \\
\text { E-cadherin } \\
\text { and p63 }\end{array}$ & $\begin{array}{l}\text { Lin et al. } \\
\text { [37] }\end{array}$ \\
\hline & $\begin{array}{l}\text { Corneal } \\
\text { chemical burn } \\
\text { ( } 6 \mathrm{~mm} \varnothing \text { disc } \\
1 \mathrm{~N} \mathrm{NaOH} \mathrm{30s} \\
\text { on the upper } \\
\text { cornea) }\end{array}$ & $\begin{array}{l}\text { Combined administration: } \\
\text { AT-MSCs }\left(2 \times 10^{6} / 500 \mu \mathrm{ll}\right) \\
\text { from rabbit by topical ad- } \\
\text { ministration + stromal } \\
\text { pocket }+ \text { subconjunctival } \\
\text { injection (immediately after } \\
\text { injury) }\end{array}$ & $\begin{array}{l}3,7,14 \\
21, \text { and } \\
28 \text { days }\end{array}$ & $\begin{array}{l}\downarrow \text { Corneal opacity } \\
\downarrow \text { Neovascularization } \\
\text { (\VEGF) } \\
\downarrow \text { Epithelial defect }\end{array}$ & - & $\downarrow$ Inflammation & - & $\begin{array}{l}\text { Almaliotis } \\
\text { et al. [65] }\end{array}$ \\
\hline & $\begin{array}{l}\text { Partial corneal/ } \\
\text { limbal }\end{array}$ & $\begin{array}{l}\text { Human BM-MSCs or hu- } \\
\text { man limbal MSCs: one }\end{array}$ & $\begin{array}{l}7,14 \\
28 \text { days, }\end{array}$ & $\begin{array}{l}\downarrow \text { Corneal opacity } \\
\downarrow \text { Neovascularization }\end{array}$ & $\begin{array}{l}\text { Human } \\
\text { limbal }\end{array}$ & - & - & $\begin{array}{l}\text { Li et al. } \\
\text { [39] }\end{array}$ \\
\hline
\end{tabular}


Table 1 Subconjunctival injection of MSCs in experimental models of corneal epithelial damage (Continued)

\begin{tabular}{|c|c|c|c|c|c|c|c|c|}
\hline Species & $\begin{array}{l}\text { Experimental } \\
\text { model }\end{array}$ & Cell administration route & $\begin{array}{l}\text { Follow- } \\
\text { up } \\
\text { time }\end{array}$ & Clinical signs & $\begin{array}{l}\text { Cell } \\
\text { migration }\end{array}$ & $\begin{array}{l}\text { Anti-inflammatory/ } \\
\text { immunomodulatory } \\
\text { effects }\end{array}$ & $\begin{array}{l}\text { Corneal/ } \\
\text { limbal } \\
\text { markers }\end{array}$ & Reference \\
\hline & 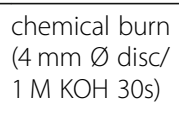 & $\begin{array}{l}\text { injection }\left(5 \times 10^{3} / 200 \mu \mathrm{l}\right) \\
\text { immediately after damage }\end{array}$ & $\begin{array}{l}\text { and } 3 \\
\text { months }\end{array}$ & $\begin{array}{l}\downarrow \text { Epithelial defect } \\
\downarrow \text { Goblet cells in the } \\
\text { cornea }\end{array}$ & $\begin{array}{l}\text { MSC: } \\
\text { migration } \\
\text { to the } \\
\text { cornea }\end{array}$ & & & \\
\hline
\end{tabular}

prolonging corneal allograft survival, reducing corneal opacity and neovascularization [67].

The administration of xenogeneic MSCs from human limbal stroma can reduce corneal opacity, neovascularization, and epithelial defects in alkali-burned corneas of rats [63] and rabbits [39]. Also, human limbal MSCs were more effective than human BM-MSCs in reducing the clinical signs [39]. Further, two corneal alkali burn models developed in rabbits have demonstrated that epithelial defects, corneal opacity, and neovascularization can be reduced by injecting a single dose of human ATMSCs [37] or BM-MSCs [39]. Finally, in a partial LSCD model developed in rabbits, subconjunctival injection of AT-MSCs in combination with both topical application and injection into stromal pockets reduced the clinical signs of corneal opacity, neovascularization, and epithelial defects [65].

Clearly from the above considerations, it is not easy to directly compare the results from different works because each is performed under different conditions and protocols. However, it is interesting that, especially in rat models, even with different cell doses, different number of injections, and also different times of the injection, there is always improved corneal transparency, fewer epithelial defects, and decreased neovascularization. Therefore, to compare the outcomes more precisely, it is necessary to study the effects of MSCs derived from the same origin but applied in different doses and routes of applications in the same animal model. This approach will facilitate making comparisons and deciding which protocol gives the best results for that model, and perhaps provide insight regarding the application to human ocular surface disease.

\section{MSC migration after subconjunctival injection}

MSCs can migrate to injured and inflamed areas through a mechanism that is mediated mainly by the chemokine CXCL12 that is produced in the damaged tissues and by the CXCR4 receptor present in the MSCs [68]. In diabetic mice with mechanical damage to the cornea and limbus, 2 days after subconjunctival administration of $5 \times 10^{4}$ mouse BM-MSCs, Di et al. observed migration of the cells to the stroma of the corneal wound edge and also to the limbal stroma [33]. Consistent with these results, Shukla et al. also demonstrated the migration of mouse BM-MSCs to the corneal and conjunctival stroma
4 days after subconjunctival injection of $5 \times 10^{5}$ cells in a mouse model of corneal mechanical injury [62]. Additionally, human limbal MSCs migrated from the limbus to the corneal epithelium 4 weeks after subconjunctival administration of $5 \times 10^{3}$ and $2.4 \times 10^{6}$ cells in rabbit and rat corneal burn models, respectively $[39,63]$.

However, not all studies have documented MSC migration from the injection site to the wound site. Four weeks after rat corneas received alkali burns and after subconjunctival administration of $1 \times 10^{6}$ or $2 \times 10^{6}$ rat BM-MSCs, Ghazaryan et al. [34], Yao et al. [35], and Zhang et al. [64] found no evidence of MSC migration to the corneas, demonstrating that the injected cells remained in the injection site. Additionally, human BMMSCs showed no engraftment in the cornea of a mouse GVHD model 18 days after subconjunctival administration of $2 \times 10^{5}$ human BM-MSCs [66]. However, the therapeutic effect of the MSCs was evident, indicating that the beneficial role of these cells is facilitated by trophic factors. It should be noted that in studies where no migration was observed, the MSCs were administered 3,7 , or 10 days after the creation of the damage [34, 35, 66]. In contrast, in most of the studies where the MSCs were injected on the same day that the injury was induced, migration to the limbus or cornea occurred [33, 62]. Thus, the delay in the administration of MSCs could induce a decrease in the migratory capacity of the cells due to a decrease in the signals released by the damaged tissues. Based on this hypothesis, it would be important to study how CXCL12 expression changes in the damaged tissues over time. The disparity in results is difficult to analyze because the studies used cells from different sources and species. A comparative study of CXCR4 expression in MSCs from different species and sources could provide insight regarding species-specific differences in MSC migration patterns.

Anti-inflammatory and immunomodulatory effects of MSC subconjunctival injection in corneal epithelial damage

Several works have demonstrated the well-known antiinflammatory effects of subconjunctivally injected MSCs $[33,34,36,63]$. Investigations in mice demonstrated that subconjunctival injection of mouse-derived BM-MSCs produced a lower ocular surface inflammatory response in corneal mechanical damage models, preventing the infiltration of CD45-positive cells [62] and macrophages 
(CD86+) [33] into the cornea. Moreover, the secretion of some pro-inflammatory cytokines such as tumor necrosis factor (TNF)- $\alpha$, interleukin (IL)-1 $\beta$, and myocyte chemoattractant protein (MCP)-1 was reduced after subconjunctival injection of mouse BM-MSCs in these models [33, 62]. Additionally, Di et al. showed that TNF- $\alpha$ stimulated gene/protein (TSG)- 6 combined with the MSCs, transformed the inflammatory monocytes into macrophages in the M2 state, limiting the immune response and expression of pro-inflammatory genes [33]. Furthermore, infiltration of $\mathrm{T}$ lymphocytes (CD3+) and expression of TNF- $\alpha$ were reduced in the ocular surface of a mouse GVHD model subconjunctivally treated with human BM-MSCs [66].

In different models of rat corneal burns, subconjunctival injections of rat BM-MSCs reduced infiltration of CD68+ macrophages and other inflammatory cells [3436, 64]. Moreover, these studies agree on the decreased expression of pro-inflammatory cytokines such as TNF$\alpha$, IL-1, IL- 6 , and the chemotactic factors MIP- $1 \alpha$ and MCP-1 in BM-MSC-treated rats [35, 36, 64]. Interestingly, Zhang et al. demonstrated that TNF- $\alpha$-pre-stimulated BM-MSCs were more efficient at reducing inflammation than non-stimulated BM-MSCs [64]. Additionally, the increase in the expression of prostaglandinendoperoxide synthase 2 and TSG- 6 in the corneas treated with stimulated and non-stimulated BM-MSCs indicates that these molecules are implicated in the antiinflammatory effect of the BM-MSCs [64]. Lu et al. confirmed that BM-MSC injection in a rat model of corneal allograft rejection decreased not only the CD68+ cells, but also the CD4+ $\mathrm{T}$ cells. At the molecular level, the anti-inflammatory action of this treatment was confirmed by (1) an increase in Ptprc gene expression, considered a CD45 antigen that regulates B and T cells, and (2) a reduction of Hspa 8 that is involved in inflammatory processes via MAPK [67].

Therefore, all of these works demonstrate that subconjunctivally injected MSCs reduce the infiltration of inflammatory cells into the cornea and decrease mainly TNF- $\alpha$ expression at the site of injury, promoting a less inflammatory microenvironment. Moreover, TSG-6 could be one of the molecules involved in the antiinflammatory effect of the MSCs in the cornea.

\section{Expression of corneal/limbal epithelial markers after MSC subconjunctival injection}

Analysis of corneal and limbal epithelial cell markers in the treated ocular surfaces is used to document the recovery of the specific cellular phenotypes after the subconjunctival injection of MSCs. In corneas of diabetic mice that were subconjunctivally injected with BMMSCs, there was increased expression of the limbal epithelial stem cell marker p63 and decreased expression of the differentiated corneal epithelial cell marker K12 [33]. However, following alkali burn in rabbits, the expression of the corneal epithelial cell marker connexin 43 and the pro-proliferative marker $\beta$-catenin increased after ATMSC injection [37]. In contrast, there were no differences in the corneal epithelial cell marker E-cadherin or in the limbal epithelial stem cell marker p63 expression after the treatment. To date, the role of the subconjunctivally administered MSCs in the recovery of the corneal and limbal phenotype is not clear yet. Consequently, this is an important field to further investigate.

\section{Subconjunctival injection of MSCs in clinical trials for treating corneal epithelial damage in humans}

To date, five clinical trials appear in the database of the US National Institutes of Health ClinicalTrials.gov (Table 2), and to the best of our knowledge, no results have been published yet for any of these clinical trials. The first clinical trial performed by Boto et al. (Madrid, Spain) (clinicaltrials.gov_NCT01808378) was an interventional, phase 2, single-arm trial that has been completed according to Clinicaltrialsregister.eu (clinicaltrialsregister.eu_ 2010-024328-53). In this case, autologous AT-MSCs were used to treat total bilateral LSCD in 8 patients, applying 4 subconjunctival injections $\left(4 \times 10^{6}\right.$ AT-MSCs per quadrant). Additionally, AMs were used, and $4 \times 10^{6}$ AT-MSCs were topically dispensed to the damaged eye. The primary outcome in this trial was the feasibility and safety of autologous expanded lipoaspirated stem cells following 16 weeks of treatment for bilateral limbal-associated keratopathy. However, no results have been reported so far.

A new interventional, phase 1-2, three-arm parallel assignment, non-randomized, and unmasked clinical trial was carried out by Volotovsky et al. (Minsk, Belarus) and completed in 2019 (clinicaltrials.gov_NCT04484402). In this case, both autologous AT-MSCs and limbal stem cells were applied in 25 patients with inflammatory-dystrophic diseases of the cornea. Although no results have been published yet, treatment-related adverse effects and the number of cured patients were evaluated for 4 weeks and 2 months, respectively.

In addition, there are two more single-arm clinical trials in which subconjunctival injection of human BMMSCs are being used to treat corneal chemical burns. The first one (clinicaltrials.gov_NCT02325843), under the direction of Dan et al. (Guangzhou, China), has been completed but no results have been reported so far. In it, one injection of $5 \times 10^{6}$ human BM-MSCs was applied in 16 patients. This was followed by a second injection if a persistent epithelial defect was detected. The percentage of corneal perforations that occurred during a 3month follow-up was analyzed, and different adverse events, such as ocular infection, conjunctival necrosis at the injection site, and retinal artery occlusion, as well as 
Table 2 Currently active clinical trials exploring subconjunctival injection of MSCs for treating corneal epithelial damages

\begin{tabular}{|c|c|c|c|c|c|c|}
\hline $\begin{array}{l}\text { ClinicalTrials.gov } \\
\text { identifier / } \\
\text { Clinicaltrialsregister.eu } \\
\text { identifier }\end{array}$ & $\begin{array}{l}\text { Condition } \\
\text { or disease }\end{array}$ & Cell administration & Study design & $\begin{array}{l}\text { Number } \\
\text { of } \\
\text { patients }\end{array}$ & $\begin{array}{l}\text { Sponsor and } \\
\text { performing } \\
\text { center }\end{array}$ & $\begin{array}{l}\text { Status and } \\
\text { initiation date }\end{array}$ \\
\hline $\begin{array}{l}\text { NCT01808378 / } \\
\text { EudraCT2010-024328-53 }\end{array}$ & $\begin{array}{l}\text { Keratopathy } \\
\text { associated } \\
\text { with } \\
\text { bilateral } \\
\text { LSCD }\end{array}$ & $\begin{array}{l}\text { Human autologous AT-MSCs: } 4 \\
\text { injections ( } 4 \times 10^{6} \text { MSCs per } \\
\text { quadrant) + topical application } \\
\text { of } 4 \times 10^{6} \text { MSCs for } 20 \mathrm{~min}+ \\
\text { amniotic membrane }\end{array}$ & $\begin{array}{l}\text { Interventional, } \\
\text { phase } 2 \text {, single } \\
\text { arm, unmasked }\end{array}$ & 8 & $\begin{array}{l}\text { Research Institute } \\
\text { of La Paz University } \\
\text { Hospital, Madrid, } \\
\text { Spain }\end{array}$ & $\begin{array}{l}\text { Completed } \\
\text { according to } \\
\text { clinicaltrialsregister.eu } \\
2012\end{array}$ \\
\hline NCT02325843 & $\begin{array}{l}\text { Corneal } \\
\text { chemical } \\
\text { burn }\end{array}$ & $\begin{array}{l}\text { Human BM-MSCs: } 1 \text { injection of } \\
5 \times 10^{6} \mathrm{MSC} / 500 \mu \mathrm{l}+\text { amniotic } \\
\text { membrane. If persistent epithe- } \\
\text { lial defect was noted, a second } \\
\text { injection was performed. }\end{array}$ & $\begin{array}{l}\text { Interventional, } \\
\text { phase } 2 \text {, single } \\
\text { arm, unmasked }\end{array}$ & 16 & $\begin{array}{l}\text { Sun Yat-sen Univer- } \\
\text { sity, Guangzhou, } \\
\text { China }\end{array}$ & $\begin{array}{l}\text { Completed } \\
2014\end{array}$ \\
\hline NCT04484402 & $\begin{array}{l}\text { Corneal } \\
\text { ulcer, } \\
\text { corneal } \\
\text { disease, } \\
\text { corneal } \\
\text { dystrophy }\end{array}$ & $\begin{array}{l}\text { Autologous AT-MSCs + sodium } \\
\text { hyaluronate } 1 \% \text { solution } \\
\text { Autologous limbal stem cells + } \\
\text { sodium hyaluronate } 1 \% \\
\text { solution }\end{array}$ & $\begin{array}{l}\text { Interventional, } \\
\text { phase 1-2, three- } \\
\text { arm parallel as- } \\
\text { signment, non- } \\
\text { randomized, } \\
\text { unmasked }\end{array}$ & 25 & $\begin{array}{l}\text { Institute of } \\
\text { Biophysics and Cell } \\
\text { Engineering of } \\
\text { National Academy } \\
\text { of Sciences of } \\
\text { Belarus }\end{array}$ & $\begin{array}{l}\text { Completed } \\
2016\end{array}$ \\
\hline NCT03237442 & $\begin{array}{l}\text { Corneal } \\
\text { chemical } \\
\text { burn }\end{array}$ & $\begin{array}{l}\text { Human umbilical cord MSCs: } 1 \\
\text { injection of } 2 \times 10^{6} \mathrm{MSCs} / \\
200 \mu \mathrm{l}\end{array}$ & $\begin{array}{l}\text { Interventional, } \\
\text { phase 1-2, two- } \\
\text { arm parallel as- } \\
\text { signment, ran- } \\
\text { domized, double } \\
\text { masked }\end{array}$ & 100 & $\begin{array}{l}\text { Guangzhou Saliai } \\
\text { Stem Cell Science } \\
\text { and Technology } \\
\text { Co. Ltd., China }\end{array}$ & $\begin{array}{l}\text { Not yet recruiting } \\
\text { (unknown status) } \\
2017\end{array}$ \\
\hline NCT03967275 & $\begin{array}{l}\text { Corneal } \\
\text { chemical } \\
\text { burn }\end{array}$ & Allogeneic human BM-MSCs & $\begin{array}{l}\text { Observational, } \\
\text { single arm }\end{array}$ & 3 & $\begin{array}{l}\text { Ophthalmological } \\
\text { Foundation } \\
\text { Adolphe de } \\
\text { Rothschild, Paris, } \\
\text { France }\end{array}$ & $\begin{array}{l}\text { Not yet recruiting } \\
2019\end{array}$ \\
\hline
\end{tabular}

Data from www.ClinicalTrials.gov and www.clinicaltrialsregister.eu

systemic complications during 6 months of follow-up, were also studied. The second single-arm clinical trial (clinicaltrials.gov_NCT03967275) by Gabison et al. (Paris, France) is still recruiting patients, and the dose of allogeneic human BM-MSCs is still unknown.

Finally, an as yet uninitiated interventional, phase 1-2, two-arm parallel assignment, randomized, and doublemasked clinical trial (clinicaltrials.gov_NCT03237442) by Ma et al. (Guangdong, China) will compare the subconjunctival injection of $2 \times 10^{6}$ human umbilical cord MSCs versus saline injection as potential treatment of corneal chemical burns.

\section{Conclusions}

MSCs have several properties that make them a good choice for cell therapy in different tissues, including the cornea. The administration route is an important limiting factor for these treatments, as it should be safe and, when possible, minimally invasive. Subconjunctival injections are a minimally invasive and straightforward technique that is routinely used in ophthalmology to deliver drugs. Recent work has clearly shown that it can also deliver cellbased therapies, allowing the administration of higher cell doses. In addition, this technique could reduce costs as no substrata or surgical procedures are required.
Considering all the basic and translational investigations related to subconjunctival injection of MSCs for corneal regeneration, the convenience and interest of this technique is evident. Nevertheless, although the results of existing preclinical studies are very encouraging, to conclusively state that subconjunctival injections are a safe and effective route to administer MSCs to the ocular surface, it is necessary to carry out more of these studies. Additionally, the available clinical data from the ongoing clinical trials is still limited and insufficient; therefore, more clinical evidence is required to conclude if one route of administration is better than another in terms of clinical safety and efficacy. Nevertheless, considering the regenerative and anti-inflammatory effects shown by subconjunctival injection of MSCs in experimental models of corneal epithelial damage [33-39, 62-65] and the promising results obtained in the first clinical trial performed and published using BM-MSCs on AMs for treating patients suffering from LSCD [12], good efficacy would also be expected in LSCD patients when MSCs are administered by subconjunctival injections.

\section{Abbreviations}

AM: Amniotic membrane; AT: Adipose tissue; BM: Bone marrow; GVHD : Graft versus host disease; IL: Interleukin; LESC: Limbal epithelial stem cells; LSCD: Limbal stem cell deficiency; MCP: Monocyte chemoattractant protein; 
MHC: Major histocompatibility complex; MIP: Macrophage inflammatory protein; MSC: Mesenchymal stem cells; TGF: Transforming growth factor; TNF: Tumor necrosis factor; TSG: Tumor necrosis factor-a-stimulated gene/ protein; TSP: Thrombospondin; VEGF: Vascular endothelial growth factor

\section{Acknowledgements}

We thank B. Bromberg (Certified Editor in the Life Sciences, Xenofile Editing, www.xenofileediting.com) for his assistance in the final editing and preparation of this manuscript.

\section{Authors' contributions}

SG and AM searched and analyzed the literature and were the major contributors in writing the manuscript. MLP, IP, JMH, MC, and TNM made substantial contributions to the conception, design, and content of the manuscript. MC and TNM provided financial support. All of the authors read and approved the final version of the manuscript.

\section{Funding}

This work was supported by the Department of Education, Castilla y León Regional Government (Grant VA268P18 FEDER, EU), Spain; Ministry of Science and Innovation (Grant PID2019-105525RB-100, MICINN/FEDER), Spain; Institute of Health Carlos III, CIBER-BBN (CB06/01/003 MICINN/FEDER, EU), Spain; and the Regional Center for Regenerative Medicine and Cell Therapy, Castilla y León, Spain.

\section{Availability of data and materials}

Not applicable

\section{Ethics approval and consent to participate}

Not applicable

\section{Consent for publication}

Not applicable

\section{Competing interests}

The authors declare that they have no competing interests.

\section{Author details}

'Instituto de Oftalmobiología Aplicada (IOBA), Universidad de Valladolid, Edificio IOBA, Campus Miguel Delibes, Paseo de Belén 17, 47011 Valladolid, Spain. ${ }^{2}$ Centro de Investigación Biomédica en Red de Bioingeniería, Biomateriales y Nanomedicina (CIBER-BBN), Instituto de Salud Carlos III, Madrid, Spain. ${ }^{3}$ Centro en Red de Medicina Regenerativa y Terapia Celular de Castilla y León, Valladolid, Spain.

\section{Received: 21 October 2020 Accepted: 28 December 2020} Published online: 13 January 2021

\section{References}

1. Cotsarelis G, Cheng SZ, Dong G, Sun TT, Lavker RM. Existence of slowcycling limbal epithelial basal cells that can be preferentially stimulated to proliferate: implications on epithelial stem cells. Cell. 1989;57(2):201-9 https://doi.org/10.1016/0092-8674(89)90958-6.

2. Schlötzer-Schrehardt U, Kruse FE. Identification and characterization of limbal stem cells. Exp Eye Res. 2005;81:247-64 https://doi.org/10.1016/j.exer. 2005.02.016

3. Schermer A, Galvin S, Sun TT. Differentiation-related expression of a major $64 \mathrm{~K}$ corneal keratin in vivo and in culture suggests limbal location of corneal epithelial stem cells. J Cell Biol. 1986;103:49-62 http://www.ncbi. nlm.nih.gov/pubmed/2424919.

4. Li W, Hayashida Y, Chen YT, Tseng SCG. Niche regulation of corneal epithelial stem cells at the limbus. Cell Res. 2007;17(1):26-36. https://doi.org/ 10.1038/sj.cr.7310137.

5. Yazdanpanah G, Haq Z, Kang K, Jabbehdari S, Rosenblatt ML, Djalilian AR. Strategies for reconstructing the limbal stem cell niche. Ocul Surf. 2019; 17(2):230-40 https://doi.org/10.1016/j.jtos.2019.01.002

6. Pellegrini G, Traverso CE, Franzi AT, Zingirian M, Cancedda R, De Luca M Long-term restoration of damaged corneal surfaces with autologous cultivated corneal epithelium. Lancet. 1997:349:990-3 7. https://doi.org/10. 1056/NEJMoa0905955.
7. Rama P, Matuska S, Paganoni G, Spinelli A, De Luca M, Pellegrini G. Limbal stem-cell therapy and long-term corneal regeneration. N Engl J Med. 2010; 363(2):147-55 https://doi.org/10.1056/NEJMoa0905955.

8. Baylis O, Figueiredo F, Henein C, Lako M, Ahmad S. 13 years of cultured limbal epithelial cell therapy: a review of the outcomes. J Cell Biochem. 2011;112(4):993-1002 https://doi.org/10.1002/jcb.23028.

9. Zhao Y, Ma L. Systematic review and meta-analysis on transplantation of ex vivo cultivated limbal epithelial stem cell on amniotic membrane in limbal stem cell deficiency. Cornea. 2015;34:592-600 https://doi.org/10. 1097/ICO.0000000000000398.

10. Ramírez BE, Sánchez A, Herreras JM, Fernández I, García-Sancho J, NietoMiguel T, et al. Stem cell therapy for corneal epithelium regeneration following good manufacturing and clinical procedures. Biomed Res Int. 2015;408495 https://doi.org/10.1155/2015/408495.

11. Berebichez-Fridman R, Montero-Olvera PR. Sources and clinical applications of mesenchymal stem cells state-of-the-art review. Sultan Qaboos Univ Med J. 2018;18:e264-77 https://doi.org/10.18295/squmj.2018.18.03.002.

12. Calonge M, Pérez I, Galindo S, Nieto-Miguel T, López-Paniagua M, Fernández I, et al. A proof-of-concept clinical trial using mesenchymal stem cells for the treatment of corneal epithelial stem cell deficiency. Transl Res. 2019;206: 18-40 https://doi.org/10.1016/j.trsl.2018.11.003.

13. Rafiei F, Tabesh H, Farzad F. Sustained subconjunctival drug delivery systems: current trends and future perspectives. Int. Ophthalmol. 2020;40(9): 2385-401 https://doi.org/10.1007/s10792-020-01391-8.

14. Cejkova J, Trosan P, Cejka C, Lencova A, Zajicova A, Javorkova E, et al. Suppression of alkali-induced oxidative injury in the cornea by mesenchymal stem cells growing on nanofiber scaffolds and transferred onto the damaged corneal surface. Exp Eye Res. 2013;116:312-23 https:// doi.org/10.1016/j.exer.2013.10.002.

15. Zeppieri M, Salvetat ML, Beltrami AP, Cesselli D, Bergamin N, Russo R, et al. Human adipose-derived stem cells for the treatment of chemically burned rat cornea: preliminary results. Curr Eye Res. 2013;38:451-63 https://doi.org/ 10.3109/02713683.2012.763100

16. Oh JY, Kim MK, Shin MS, Lee HJ, Ko JH, Wee WR, et al. The antiinflammatory and anti-angiogenic role of mesenchymal stem cells in corneal wound healing following chemical injury. Stem Cells. 2008;26:104755 https://doi.org/10.1634/stemcells.2007-0737.

17. Galindo S, Herreras JM, López-Paniagua M, Rey E, de la Mata A, PlataCordero $\mathrm{M}$, et al. Therapeutic effect of human adipose tissue-derived mesenchymal stem cells in experimental corneal failure due to limbal stem cell niche damage. Stem Cells. 2017;35:2160-74 https://doi.org/10.1002/ stem.2672.

18. Rohaina $\mathrm{CM}$, Then $\mathrm{KY}, \mathrm{Ng}$ AMH, Wan Abdul Halim WH, Zahidin AZM, Saim A, et al. Reconstruction of limbal stem cell deficient corneal surface with induced human bone marrow mesenchymal stem cells on amniotic membrane. Transl Res. 2014;163:200-10 https://doi.org/10.1016/j.trsl.2013.11.004

19. Jiang TS, Cai L, Ji WY, Hui YN, Wang YS, Hu D, et al. Reconstruction of the corneal epithelium with induced marrow mesenchymal stem cells in rats. Mol Vis. 2010:16:1304-16

20. Ma Y, Xu Y, Xiao Z, Yang W, Zhang C, Song E, et al. Reconstruction of chemically burned rat corneal surface by sone marrow-derived human mesenchymal stem cells. Stem Cells. 2006;24:315-21 https://doi.org/10. 1634/stemcells.2005-0046.

21. Pmarli FA, Okten G, Beden U, Fisgm T, Kefeli M, Kara N, et al. Keratinocyte growth factor-2 and autologous serum potentiate the regenerative effect of mesenchymal stem cells in cornea damage in rats. Int J Ophthalmol. 2014;7: 211-9 https://doi.org/10.3980/j.issn.2222-3959.2014.02.05

22. Gu S, Xing C, Han J, Tso MOM, Hong J. Differentiation of rabbit bone marrow mesenchymal stem cells into corneal epithelial cells in vivo and ex vivo. Mol Vis. 2009;15:99-107.

23. Holan V, Trosan P, Cejka C, Javorkova E, Zajicova A, Hermankova B, et al. A comparative study of the therapeutic potential of mesenchymal stem cells and limbal epithelial stem cells for ocular surface reconstruction. Stem Cells Transl Med. 2015;4:1052-63 https://doi.org/10.5966/sctm.2015-0039.

24. Cejka C, Holan V, Trosan P, Zajicova A, Javorkova E, Cejkova J. The favorable effect of mesenchymal stem cell treatment on the antioxidant protective mechanism in the corneal epithelium and renewal of corneal optical properties changed after alkali burns. Oxidative Med Cell Longev. 2016;2016: 5843809 https://doi.org/10.1155/2016/5843809.

25. Zajicova A, Pokorna K, Lencova A, Krulova M, Svobodova E, Kubinova S, et al. Treatment of ocular surface injuries by limbal and mesenchymal stem 
cells growing on nanofiber scaffolds. Cell Transplant. 2010;19:1281-90 https://doi.org/10.3727/096368910X509040.

26. Mittal SK, Omoto M, Amouzegar A, Sahu A, Rezazadeh A, Katikireddy KR, et al. Restoration of corneal transparency by mesenchymal stem cells. Stem Cell Reports. 2016;7:583-90 https://doi.org/10.1016/j.stemcr.2016.09.001.

27. Ye J, Yao K, Kim JC. Mesenchymal stem cell transplantation in a rabbit corneal alkali burn model: engraftment and involvement in wound healing. Eye. 2006;20:482-490. https://doi.org/10.1038/sj.eye.6701913.

28. Lan Y, Kodati S, Lee HS, Omoto M, Jin Y, Chauhan SK. Kinetics and function of mesenchymal stem cells in corneal injury. Investig Ophthalmol Vis Sci. 2012;53:3638-44 https://doi.org/10.1167/iovs.11-9311.

29. Roddy GW, Oh JY, Lee RH, Bartosh TJ, Ylostalo J, Coble K, et al. Action at a distance: systemically administered adult stem/progenitor cells (MSCs) reduce inflammatory damage to the cornea without engraftment and primarily by secretion of TNF-a stimulated gene/protein 6. Stem Cells. 2011; 29:1572-9 https://doi.org/10.1002/stem.708.

30. Lee JY oun., Jeong HJ eon., Kim MK U., Wee WR yan. Bone marrow-derived mesenchymal stem cells affect immunologic profiling Coulson-Thomas VJ, Caterson B, Kao WWY. Transplantation of human umbilical mesenchymal stem cells cures the corneal defects of mucopolysaccharidosis VII mice. Stem Cells .2013:31:2116-26. doi:10.1002/stem.1481 of interleukin-17secreting cells in a chemical burn mouse model. Korean J Ophthalmol. 2014;28:246-56. https://doi.org/10.3341/kjo.2014.28.3.246.

31. Coulson-Thomas VJ, Caterson B, Kao WWY. Transplantation of human umbilical mesenchymal stem cells cures the corneal defects of mucopolysaccharidosis vii mice. Stem Cells. 2013;31:2116-26. https://doi. org/10.1002/stem.1481.

32. Call M, Elzarka M, Kunesh M, Hura N, Birk DE, Kao WW. Therapeutic efficacy of mesenchymal stem cells for the treatment of congenital and acquired corneal opacity. Mol Vis. 2019;25:415-26.

33. Di G, Du X, Qi X, Zhao X, Duan H, Li S, et al. Mesenchymal stem cells promote diabetic corneal epithelial wound healing through TSG-6dependent stem cell activation and macrophage switch. Investig Ophthalmol Vis Sci. 2017;58:4064-74 https://doi.org/10.1167/iovs.17-21506.

34. Ghazaryan E, Zhang Y, He Y, Liu X, Li Y, Xie J, et al. Mesenchymal stem cells in corneal neovascularization: comparison of different application routes. Mol Med Rep. 2016;14:3104-12 https://doi.org/10.1167/iovs.17-21506.

35. Yao L, Li Z rong, Su W ru, Li Y ping, Lin M li, Zhang W xin, et al. Role of mesenchymal stem cells on cornea wound healing induced by acute alkali burn. PLoS One. 2012;7(2):e30842. https://doi.org/10.1371/journal.pone.0030842.

36. Ke Y, Wu Y, Cui X, Liu X, Yu M, Yang C, et al. Polysaccharide hydrogel combined with mesenchymal stem cells promotes the healing of corneal alkali burn in rats. PLoS One. 2015;10(3):e0119725 https://doi.org/10.1371/ journal.pone.0119725.

37. Lin HF, Lai YC, Tai CF, Tsai JL, Hsu HC, Hsu RF, et al. Effects of cultured human adipose-derived stem cells transplantation on rabbit cornea regeneration after alkaline chemical burn. Kaohsiung J Med Sci. 2013;29:148 https://doi.org/10.1016/j.kjms.2012.08.002.

38. Pan J, Wang X, Li D, Li J, Jiang Z. MSCs inhibits the angiogenesis of HUVECs through the miR-211/Prox1 pathway. J Biochem. 2019;166:107-13 https:// doi.org/10.1093/jb/mvz038.

39. Li G, Zhang Y, Cai S, Sun M, Wang J, Li S, et al. Human limbal niche cells are a powerful regenerative source for the prevention of limbal stem cell deficiency in a rabbit model. Sci Rep. 2018;8(1):6566 https://doi.org/10.1038/ s41598-018-24862-6.

40. Özmert E, Arslan U. Management of retinitis pigmentosa by Wharton's jelly derived mesenchymal stem cells: preliminary clinical results. Stem Cell Res Ther. 2020;11(1):25 https://doi.org/10.1186/s13287-020-1549-6.

41. Dziasko MA, Armer HE, Levis HJ, Shortt AJ, Tuft S, Daniels JT. Localisation of epithelial cells capable of holoclone formation in vitro and direct interaction with stromal cells in the native human limbal crypt. PLoS One. 2014;9(4): e94283 https://doi.org/10.1371/journal.pone.0094283.

42. Dominici M, Le Blanc K, Mueller I, Slaper-Cortenbach I, Marini FC, Krause DS, et al. Minimal criteria for defining multipotent mesenchymal stromal cells. The International Society for Cellular Therapy position statement. Cytotherapy. 2006;8:315-7 https://doi.org/10.1080/14653240600855905.

43. Zhang L, Coulson-Thomas VJ, Ferreira TG, Kao WWY. Mesenchymal stem cells for treating ocular surface diseases. BMC Ophthalmol. 2015;15 https:// doi.org/10.1186/s12886-015-0138-4.

44. Yao L, Bai H. Review: Mesenchymal stem cells and corneal reconstruction. Mol Vis. 2013;19:2237-43.
45. Li F, Zhao SZ. Control of cross talk between angiogenesis and inflammation by mesenchymal stem cells for the treatment of ocular surface diseases. Stem Cells Int. 2016;2016:7961816 https://doi.org/10.1155/2016/7961816.

46. Dabrowski FA, Burdzinska A, Kulesza A, Sladowska A, Zolocinska A, Gala K, et al. Comparison of the paracrine activity of mesenchymal stem cells derived from human umbilical cord, amniotic membrane and adipose tissue. J Obstet Gynaecol Res. 2017;43:1758-68 https://doi.org/10.1111/jog. 13432.

47. Morita SI, Shirakata Y, Shiraishi A, Kadota Y, Hashimoto K, Higashiyama S, et al. Human corneal epithelial cell proliferation by epiregulin and its crossinduction by other EGF family members. Mol Vis. 2007;13:2119-28.

48. Yang $H$, Sun X, Wang Z, Ning G, Zhang F, Kong J, et al. EGF stimulates growth by enhancing capacitative calcium entry in corneal epithelial cells. J Membr Biol. 2003;194:47-58 https://doi.org/10.1007/s00232-003-2025-9.

49. Mohan RR, Wilson SE. Ex vivo human corneal epithelial cells express membrane-bound precursor and mature soluble epidermal growth factor (EGF) and transforming growth factor (TGF) alpha proteins. Exp Eye Res. 1999:129-31 https://doi.org/10.1006/exer.1998.0568.

50. Aggarwal S, Pittenger MF. Human mesenchymal stem cells modulate allogeneic immune cell responses. Blood. 2005;105:1815-22 https://doi.org/ 10.1182/blood-2004-04-1559.

51. Li F. Mesenchymal stem cells: potential role in corneal wound repair and transplantation. World J Stem Cells. 2014;6:296 https://doi.org/10.4252/wjsc. v6.13.296.

52. Ahmed SK, Soliman AA, Omar SMM, Mohammed WR. Bone marrow mesenchymal stem cell transplantation in a rabbit corneal alkali burn mode (a histological and immune histo-chemical study). Int J Stem Cells 2015;8: 69-78. https://doi.org/10.15283/ijsc.2015.8.1.69.

53. Zhu X, Beuerman RW, Chan-Park MBE, Cheng Z, Ang LPK, Tan DTH. Enhancement of the mechanical and biological properties of a biomembrane for tissue engineering the ocular surface. Ann Acad Med. 2006;35:210-4 http://www.ncbi.nlm.nih.gov/pubmed/16625272.

54. Espandar L, Caldwell D, Watson R, Blanco-Mezquita T, Zhang S, Bunnell B. Application of adipose-derived stem cells on scleral contact lens carrier in an animal model of severe acute alkaline burn. Eye Contact Lens. 2014;40: 243-7 https://doi.org/10.1097//CL.0000000000000045.

55. Couret C, Poinas A, Volteau C, Riche VP, Le Lez ML, Errera MH, CreuzotGarcher C, Baillif S, Kodjikian L, Ivan C, Le Jumeau de Kergaradec LM, Chiffoleau A, Jobert A, Jaulin J, Biron L, Hervouet E, Weber M. Comparison of two techniques used in routine care for the treatment of inflammatory macular oedema, subconjunctival triamcinolone injection and intravitreal dexamethasone implant: medical and economic importance of this randomized controlled trial. Trials. 2020;21(1):159 https://doi.org/10.1186/ s13063-020-4066-0.

56. Austin A, Lietman T, Rose-Nussbaumer J. Update on the management of infectious keratitis. Ophthalmology. 2017;124(11):1678-89 http://10.1016/j. ophtha.2017.05.012.

57. Khan FA, Niazi SPK. Effect of pterygium morphology on recurrence with preoperative subconjunctival injection of mitomycin-C in primary pterygium surgery. J Coll Physicians Surg Pakistan. 2019;29(7):639-43. https://doi.org/10. 29271/jcpsp.2019.07.639.

58. Zhang J, Tian Q, Zheng T, Chen D, Wang Q, Ke M. Effect of multiple subconjunctival conbercept injections as an adjuvant to the surgical treatment of pterygium: a prospective randomised comparative 6-month follow-up study. Eye. 2020;34(2):408-14 https://doi.org/10.1038/s41433-019-0596-7.

59. Lakshmipathy M, Susvar P, Popet K, Rajagopal R. Subconjunctival bevacizumab and argon laser photocoagulation for preexisting neovascularization following deep lamellar anterior keratoplasty. Indian J Ophthalmol. 2019;67(7):1193-4 https://www.ijo.in/text.asp?2019/67/7/11 93/260998.

60. Ali Shah SS. Efficacy of subconjunctival injection of bevacizumab in regressing corneal neovascularisation. J Coll Physicians Surg Pakistan. 2019; 29(5):430-4. https://doi.org/10.29271/jcpsp.2019.05.430.

61. Stanley RG. Ocular clinical pharmacology. Small Anim Clin Pharmacol. 2008; https://doi.org/10.1016/B978-070202858-8.50027-0.

62. Shukla S, Mittal SK, Foulsham W, Elbasiony E, Singhania D, Sahu SK, et al. Therapeutic efficacy of different routes of mesenchymal stem cell administration in corneal injury. Ocul Surf. 2019;17:729-36. https://doi.org/ 10.1016/j.jtos.2019.07.005.

63. Acar U, Pinarli FA, Acar DE, Beyazyildiz E, Sobaci G, Ozgermen BB, et al. Effect of allogeneic limbal mesenchymal stem cell therapy in corneal 
healing: role of administration route. Ophthalmic Res. 2015;53:82-9 https:// doi.org/10.1159/000368659.

64. Zhang N, Luo X, Zhang S, Liu R, Liang L, Su W, Liang D. Subconjunctival injection of tumor necrosis factor-a pre-stimulated bone marrow-derived mesenchymal stem cells enhances anti-inflammation and anti-fibrosis in ocular alkali burns. Graefes Arch Clin Exp Ophthalmol. 2020 https://doi.org/ 10.1007/s00417-020-05017-8.

65. Almaliotis D, Koliakos G, Papakonstantinou E, Komnenou A, Thomas A, Petrakis $\mathrm{S}$, et al. Mesenchymal stem cells improve healing of the cornea after alkali injury. Graefes Arch Clin Exp Ophthalmol. 2015;253:1121-35 https://doi.org/10.1007/s00417-015-3042-y.

66. Martínez-Carrasco R, Sánchez-Abarca LI, Nieto-Gómez C, Martín García E, Sánchez-Guijo F, Argüeso P, et al. Subconjunctival injection of mesenchymal stromal cells protects the cornea in an experimental model of GVHD. Ocul Surf. 2019;17:285-94 https://doi.org/10.1016/j.jtos.2019.01.001.

67. Lu X, Chu C, Liu X, Gao Y, Wu M, Guo F, et al. High-throughput RNAsequencing identifies mesenchymal stem cell-induced immunological signature in a rat model of corneal allograft rejection. PLoS One. 2019;14(9): e0222515 https://doi.org/10.1371/journal.pone.0222515.

68. Sohni A, Verfaillie CM. Mesenchymal stem cells migration homing and tracking. Stem Cells Int. 2013;2013:130763 https://doi.org/10.1155/2013/ 130763.

\section{Publisher's Note}

Springer Nature remains neutral with regard to jurisdictional claims in published maps and institutional affiliations. 